\title{
ISOLATION AND CHARACTERIZATION OF AN ACRYLAMIDE-DEGRADING Burkholderia sp. STRAIN DR.Y27
}

\author{
Neni Gusmanizar' ${ }^{1}$, Yunus Shukor ${ }^{2}$, Johari Ramli ${ }^{2}$ and Mohd. Arif Syed ${ }^{2}$ \\ 1) Dept. of Feed and Animal Nutrition, Faculty of Animal Husbandry, \\ Andalas University, Padang, Indonesia \\ 2) Dept. of Biochemistry, Faculty of Biotechnology and Biomolecular Sciences, \\ Universiti Putra Malaysia, 43400 Serdang, Selangor, Malaysia. \\ email : gusmanizar@gmail.com
}

\begin{abstract}
Several local bacteria have been isolated from glyphosate-contaminated soils at various locations throughout Malaysia. Quantitative monitoring of acrylamide degradation was performed using High Performance Liquid Chromatography (HPLC) whilst bacterial growth was carried out by plate counting. The isolate was tentatively identified as Burkholderia sp. strain DR. Y27 based on carbon utilization profiles using Biolog GN plates and partial 16s rDNA molecular phylogeny. Highest growth was obtained at acrylamide concentrations of between 100 to $2000 \mathrm{mg} \mathrm{L}^{-1}$. Complete degradation of $850 \mathrm{mg} \mathrm{L}^{-1}$ of acrylamide occurs after ten days of incubation with concomitant cell growth. The isolate grew optimally in between $\mathrm{pH} 6.0$ and 8.0. The effect of incubation temperature on the growth of this isolate shows an optimum growth at $30^{\circ} \mathrm{C}$. Glucose, lactose, maltose, fructose, mannitol, citric acid and sucrose at an initial concentration of $1.0 \%(\mathrm{w} / \mathrm{v})$ supported growth with glucose being the best carbon source. Aliphatic amides such as 2chloroacetamide, methacrylamide, nicotinamide, acrylamide, acetamide, propionamide and urea supported growth with increasing assimilative capability from 2-chloroacetamide to urea. The characteristics of this isolate suggest that it would be useful in the bioremediation of acrylamide.
\end{abstract}

Keywords: isolation, characterization, acrylamide-degrading, Bacterium

\section{REFERENCES}

1. V. A. Myagchenkov and V. E. Proskurina, Kinetics of flocculation and densification in ocher suspension in the presence of polyacrylamide poly ethylene oxide and their 1: 1 mixture, Colloid journal of the Russian Academy of Sciences, 62(5): 588593, (2000).

2. IPCS, Acrylamide: The International Programme on Chemical Safety, $J$. Environ Health Crit., 49, (2003).

3. T. K. F. Franzen, Garshol, and N. Tomisawa, Sprayed concrete for final linings: ITA working group report, Journal of Tunnelling Underground Space Technology, 16(4): 295-309, (2001).

4. K. Svensson, L. Abramsson, W. Becker, A. Glynn, K. E. Hellenäs, Y. Lind, and J. Rosén, Dietary intake of acrylamide in
Sweden, Journal of Food Chemical and Toxicology, 41(11): 1581-1586, (2003).

5. S. M. Rogacheva, and O. V. Ignatov, The Respiratory Activity of Rhodococcus rhodochrous M8 Cells Producing NitrileHydrolyzing Enzymes, Journal of Applied Biochemistry and Microbiology, 37: 282286, (2001).

6. Auditor-General's Report, Activities and special studies of Sarawak Ministerial/Department/Agency Putrajaya Malaysia, 2005.

7. E. A. Smith, Prues, S. L and F. W. Oehme, Environmental degradation of polyacrylamide, 1. Effects of artificial Environmental conditions: Temperature, Light, and $\mathrm{pH}, \quad$ Ecotoxicology and Environmental Safety, 35: 121-135, (1996).

8. D. V. Zyzak, R. A. Sanders, M. Stojanavic, D. H. Tallmadge, B. L. Eberhart, D. K. Ewald, D. C. Gruber, T. R. Morsch, M. A. 
Strothers, G. P. Rizzi and M. D. Villagran, Acrylamide formation mechanism in heated foods, Journal of Agricultural and Food Chemistry, 51: 4782-4787, (2003).

9. L. Brown, M. M. Rhead, K. C. C. Bancroft, and N. Allen, Model studies on the degradation of acrylamide monomer, Water Research, 14:775-778, (1980).

10. A. B. Cherry, A. J. Gabaccia, H. W. Senn, The assimilation behavior of certain toxic organic compounds in natural water, Journal of Sewage Ind Wastes, 28: 11371146, (1956).

11. H. Yamada, Y. Asano, T. Hino, Y. Tani, Microbial utilisation of acrylonitrile, Journal of Fermentation Technology, 57(1): 8-14, (1979).

12. C. C. Wang and C. M. Lee, Denitrification with acrylamide in pure culture of bacteria isolated from acrylonitrile-butadiene-styrene resin manufactured for wastewater treatment, Chemosphere, 44: 1047-1053, (2001).

13. L. M. Ciskanik, J. M. Wilczek, R. D. Fallon, Purification and characterization of an enantioselective amidase from Pseudomonas chlororaphis B23, Applied and Environmental Microbiology, 61(3): 998-1003, (1995).

14. M. J. Caulfield, X. Hao, G. G. Qiao, and D. H. Salomon, Degradation on polyacrylamides, Part I, Linear polyacrylamide, Polymer, 44: 1331-1337, (2003).

15. R. Devereux, and S. S. Wilkinson, Amplification of ribosomal RNA sequences In: Akkermans ADL van Elsas JD de Bruijn FJ eds Molecular Microbial Ecology Manual, $2^{\text {nd }}$ ed, Netherlands, Kluwer Academic Publishing, 2004, 1-17.

16. D. Higgins, J. Thompson, T. Gibson, J. D. Thompson, D. G. Higgins, T. J. Gibson, CLUSTAL W: improving the sensitivity of progressive multiple sequence alignment through sequence weighting positionspecific gap penalties and weight matrix choice, Journal of Nucleic Acids Research, 22: 4673-4680, (1994).

17. T. H. Jukes, and C. R. Cantor, Evolution of protein molecules, In H. N. Munro, ed., Mammalian Protein Metabolism, Academic Press, New York, 1969, 21-132.

18. N. Saitou, and M. Nei, The neighborjoining method: a new method for reconstructing phylogenetic trees, Molecular Biology and Evolution, 4: 406.(1987).

19. J. Felsenstein, Confidence limits on phylogenies: An approach using the bootstrap, Evolution, 39: 783-791, (1985).

20. T. Margush, and F. R. McMorris, Consensus n-trees, Bulletin of Mathematical Biology, 43: 239-244, (1981).

21. R. D. M. Page, TREEVIEW: an application to display phylogenetic trees on personal computers, Journal of Computer Application in the Bioscience, 12: 357-358, (1996).

22. J. E. Brown, and P. H. Clarke, Mutations in a regulator gene allowing Pseudomonas aeruginosa 8602 to grow on butyramide, Journal of General Microbiology, 64: 329342, (1970).

23. J. Alt and K. Krisch, Isolation of an inducible amidase from Pseudomonas acidovorans AEL J, Journal of General Microbiology, 87: 260-272, (1975).

24. M. S. Nawaz, K. D. Chapatwala, J. H. Wolfram, Degradation of acetonitrile by Pseudomonas putida, Journal of Applied and Environmental Microbiology, 55: 2267-2274, (1989).

25. H. Komeda, H. Harada, S. Washika, T. Sakamoto, M. Ueda, and Y. Asano, SStereoselective piperazine-2- tertbutylcarboxamide hydrolase from Pseudomonas azotoformans IAM 1603 is a novel L-amino acid amidase, European Journal of Biochemistry, 271(8): 14651475, (2004a).

26. K. D. Chapatwala, M. S. Nawaz, J. D. Richardson, and J. H. Wolfram, Isolation and characterization of acetonitrile utilizing bacteria, Journal of Industrial Microbiology, 5: 65-69, (1990).

27. H. Komeda, H. Harada, S. Washika, T. Sakamoto, M. Ueda, and Y. Asano, A novel $R$-stereoselective amidase from Pseudomonas sp. MC13434 acting on piperazine - 2 - tert - butylcarboxamide, European Journal of Biochemistry, 271(8):1580-1590, (2004b).

28. C. Novo, R. Tata, A. Clemente, P. R. Brown, Burkholderia genome analysis reveals new enzymes belonging to the nitrilase superfamily The amidase of Burkholderia cepacia hospital isolate, 
International Journal of Biomolecular Macromolecule, 33:175-182, (2003).

29. S. Skouloubris, A. Labigne and H. De Reuse, Identification and characterization of an aliphatic amidase in Helicobacter pylori, Journal of Molecular Microbiology, 25: 989-998, (2001).

30. K. Egorova, H. Trauthwein, S. Verseck, and G. Antranikian, Purification and properties of an enantioselective and thermoactive amidase from the thermophilic actinomycete Pseudonocardia thermophila, Applied Microbiology and Biotechnology, 65: 3845, (2004).

31. E. K. Kotlova, G. G. Chestukhina, O. B. Astaurova, T. E. Leonova, A. S. Yanenko, and V. G. Debabov, Isolation and primary characterization of an amidase from Rhodococcus rhodochrous, Biochemistry 64(4): 384-389, (1999).

32. M. S. Nawaz, S. M. Billedeau and C. E. Cerniglia, Influence of selected physical parameters on the biodegradation of acrylamide by immobilized cells of Rhodococcus sp., Biodegradation, 9: 381-387, (1998).

33. A. Postec, P. Pignet, V. Cueff-Gauchard, A. Schmitt, J. Querellou, and A. Godfroy, Optimisation of growth conditions for continuous culture of the hyperthermophilic archaeon Thermococcus hydrothermalis and development of sulphur-free defined and minimal media, Research in Microbiology, 156: 82-87, (2005).
34. D. H. Baek, S. J. Kwon, S. P. Hong, M. S. Kwak, M. H. Lee, , J. J. Song, S. G. Lee, K. H. Yoon, and M. H. Sung, Characterization of a thermostable stereospecific alanine amidase from Brevibacillus borstelensis BCS-1, Journal of Applied and Environmental Microbiology, 69:980-986, (2003).

35. M. S. Nawaz, A. A. Khan, D. Bhattacharayya, P. H. Siitonen, and C. E. Cerniglia, Physical, biochemical, and immunological characterization of a thermostable amidase from Klebsiella pneumonia NCTR 1, Journal of Bacteriology, 178(8): 2397-2401, (1996).

36. M. S. Nawaz, A. A. Khan, J. E. Seng, J. E. Leakey, P. H. Siitonen, and C. E. Cerniglia, Purification and characteriazation of an acrylamide-degrading Rhodococcus sp., Applied and Environmental Microbiology, 60(9): 3343-3348, (1994).

37. G. Cappuccino and N. Sherman, Microbiology: A Laboratory Manual. Benjamin/Cumming Science Publishing California, 1998.

38. J. F. Cavins and M. Friedman, Specific modification of sulfhydryl groups with Punsaturated compounds, Journal of Biological Chemistry, 243: 3357-3360, (1968).

39. J. L. Kay-Shoemake, M. E. Watwood, R. D. Lentz, R. E. Sojka, Polyacrylamide as an organic nitrogen source for soil microorganisms with potential effects on inorganic soil nitrogen in agricultural soil, Soil Biology and Biochemistry, 30: 10451052, (1998). 